\title{
New high-sensitive rhAmp method for A1 allele detection in A2 milk samples
}

\author{
Rodrigo Giglioti ${ }^{\mathrm{a}, *}$, Gunta Gutmanis ${ }^{\mathrm{a}}$, Luciana Morita Katiki ${ }^{\mathrm{a}}$, Cintia Hiromi Okino ${ }^{\mathrm{b}}$, \\ Márcia Cristina de Sena Oliveira ${ }^{\mathrm{b}}$, Anibal Eugênio Vercesi Filho ${ }^{\mathrm{a}}$ \\ ${ }^{a}$ Instituto de Zootecnia (IZ), Rua Heitor Penteado, 56, Zip Code 13380-011 Nova Odessa, SP, Brazil \\ ${ }^{\mathrm{b}}$ Embrapa Pecuária Sudeste (CPPSE), Rod. Washington Luiz, Km 234, CP 339, Zip Code 13560-970 São Carlos, SP, Brazil
}

A R T I C L E I N F O

\section{Keywords:}

$\beta$-Casein

Genotyping

Alleles

HRM

rhAmp

\begin{abstract}
A B S T R A C T
Cows' milk may contain two types of $\beta$-casein: A1 and A2. A1 digestion is associated with the release of $\beta$ casomorphine-7 peptide, which can cause adverse gastrointestinal effects. Two methods - high-resolution melting (HRM) and rhAmp ${ }^{\circledR}$ SNP genotyping - were developed to identify the $\beta$-casein gene (CSN2) A1 and A2 alleles directly in milk. DNA milk samples from 45 animals were examined and 10 samples were also sequenced to confirm the accuracy of the assays. The analytical sensitivities of both strategies for A1 allele identification were evaluated by testing decreasing dilutions of A1 allele DNA copies (500 - 5 copies) in the A2 sample. The limits of detection for A1 in A2 samples were 10\% (100 copies) and 2\% (10 copies) for HRM and rhAmp, respectively. Both techniques were specific, differentiating between A1 and A2 alleles. However, we recommend rhAmp genotyping testing over HRM because of its enhanced sensitivity for A1.
\end{abstract}

\section{Introduction}

Milk and dairy products, especially those derived from cows' milk, are important sources of protein worldwide, providing important macro- and micronutrients, with their consumption continuing to increase worldwide (Jianqin et al., 2016; Kamiński, Cieślińska, \& Kostyra, 2007; Kamiński, Ruść, \& Cieślińska, 2006; Visioli \& Strata, 2014). Milk from dairy cows consists of two large groups of proteins: caseins and whey proteins. The caseins constitute $80 \%$ of bovine milk proteins and have four forms: $\alpha$-S1- (CSN1-S1, 39-46\%), $\alpha$-S2- (CSN1-S2, 8-11\%), $\beta$ (CSN2, 25-35\%) and $\kappa$-casein (CSN3, 9-15\%), that occur in the approximate proportions 4:1:4:1, respectively (Grosclaude, 1988; Visser, Slangen, \& Rollema, 1991).

There are 13 genetic variants of $\beta$-casein, the most frequent of which found in cattle are A1 and A2 variants (Farrell et al., 2004). Differences between $\mathrm{A} 1$ and $\mathrm{A} 2 \beta$-casein are due to a mutation at amino acid 67 (proline at A2 to histidine at A1) (Bonfatti, Di Martino, Cecchinato, Vicario, \& Carnier, 2010). Histidine present at position 67 in $\mathrm{A} 1 \beta$-casein results in the cleavage of the preceding seven amino acid residues, generating the peptide $\beta$-casomorphin-7 ( $\beta$ CM-7) (Jinsmaa \& Yoshikawa, 1999). Compared to A2, the CSN2 A1 variant is more easily hydrolysed by digestive enzymes present in the human gastrointestinal tract, due to weaker binding between the isoleucine and histidine, releasing the peptide $\beta$-casomorphine-7 ( $\beta \mathrm{CM}-7$ ) (De Noni \& Cattaneo, 2010; De Noni, 2008; Nguyen, Johnson, Busetti, \& Solah, 2015). BCM-7 obtained after A1 milk digestion may be associated with increased risk of diseases, such as Type 1 diabetes mellitus (Chia et al., 2017), autism (Jarmołowska et al., 2019; Whiteley et al., 2010), schizophrenia (Severance et al., 2010) and increased gastrointestinal inflammation (Jianqin et al., 2016). Milk containing A2 $\beta$-casein is associated with reduced gastrointestinal symptoms of milk intolerance and enhanced lactase activity compared to conventional milk containing A1 $\beta$-casein (He, Sun, Jiang, \& Yang, 2017).

No existing reports have found the A2 allele of $\beta$-casein to be related to adverse health problems. Even under physiological conditions, the opioid peptide $\beta C M-7$ is reportedly released from A1 milk digestion, but not from A2 (Brooke-Taylor, Dwyer, Woodford, \& Kost, 2017). According to Brooke-Taylor et al.'s study, this difference is associated with slower gastrointestinal transit and consequently increased gastrointestinal transit times. The authors also demonstrated that according to some human groups, the A1-derivative peptide $\beta C M-7$ is pro-inflammatory. Thus, the consumption of A2 milk may be considered as a dietary alternative for individuals exhibiting gastrointestinal discomfort owing to the consumption of cow's milk, unrelated to lactose

\footnotetext{
* Corresponding author.

E-mail addresses: giglioti@iz.sp.gov.br (R. Giglioti), gunta@iz.sp.gov.br (G. Gutmanis), lmkatiki@iz.sp.gov.br (L.M. Katiki), cintia.okino@embrapa.br (C.H. Okino), marcia.sena-oliveira@embrapa.br (M.C. de Sena Oliveira), anibal@iz.sp.gov.br (A.E. Vercesi Filho).
} 
intolerance.

Given the relationship between CSN2 A1 and A2 as well as their impacts on human health, these two variants have been extensively studied in dairy herds (Gustavsson et al., 2014; Kamiński, Ruść, \& Cieślińska, 2006; Keating, Smith, Ross, \& Cairns, 2008; Lien et al., 1999; Rangel et al., 2017; Royo, del Cerro, Vicente, Carballal, \& RozaDelgado, 2014; Visker et al., 2010). However, there remains no standard method for genotyping these alleles of the CSN2 gene directly in milk. Moreover, most research is strictly related to genotyping the animals, whereas the present study is focused on the identification of A1 presence/contamination in A2 milk samples.

High-resolution melting (HRM) is a post-PCR method that allows detection of subtle sequence polymorphisms, by monitoring the melting behaviour of PCR amplicons using a highly saturating fluorescent dye (Wittwer, Reed, Gundry, Vandersteen, \& Pryor, 2003). Alternatively, the $\mathrm{rhAmp}^{\circledast}$ method uses RNase $\mathrm{H} 2$ to activate primers after they have become successfully bound to their target sites, reducing primer dimer formation and improving the specificity of the reaction (Dobosy et al., 2011). For the rhAmp assay, the biallelic discrimination is achieved through the competitive binding of two allele-specific forward primers, one labelled with fluorescein amidite (FAM) dye and the other with Yakima Yellow (YY) dye. Therefore, this study seeks to develop and compare these different rapid methods for the genotyping of A1 and A2 alleles directly in milk samples.

\section{Material and methods}

\subsection{Experimental samples and processing}

Blood and milk samples were provided by a commercial farm (Descalvado, Brazil; $21^{\circ} 54^{\prime} 14^{\prime \prime}$ S, $47^{\circ} 36^{\prime} 10^{\prime \prime}$ W). Twenty Holstein cows that had previously been genotyped by DNA sequencing as A1 or A2 ( $n=10)$ were used during the development of the assays. Milk samples were also individually collected from another 35 Holstein cows. In addition, five samples of A2A2 commercial milk were obtained from five different milking batches and were processed.

All procedures were approved by the Animal Science Institute Ethical Committee for Animal Experimentation (CEUA-IZ) in accordance with the ethical principles and guidelines of animal experimentation adopted by the Brazilian College of Experimentation (Process Number 238-16).

\subsection{DNA extraction}

DNA extraction was performed using an Easy-DNA ${ }^{\mathrm{TM}}$ kit (Cat. no. K1800-01-Protocol \#1-Small Blood Samples and Hair Follicles; Invitrogen, Carlsbad, US), as recommended by the manufacturer. Briefly, $60 \mu \mathrm{L}$ of whole blood was mixed with $100 \mu \mathrm{L}$ of Solution A and incubated at $65{ }^{\circ} \mathrm{C}$ for $10 \mathrm{~min} .40 \mu \mathrm{L}$ of Solution B and $140 \mu \mathrm{L}$ of chloroform were added, mixed and centrifuged at $20,817 \times g$ and $4{ }^{\circ} \mathrm{C}$ (all centrifugation steps were conducted at the same velocity and temperature) for $15 \mathrm{~min}$. The supernatant was separated in new microtubes and $445 \mu \mathrm{L}$ of Tris-EDTA and $5 \mu \mathrm{L}$ of mussel glycogen were added and mixed. One millilitre of absolute ethanol was added, mixed and incubated in ice for $30 \mathrm{~min}$. Microtubes were centrifuged for $15 \mathrm{~min}$. The supernatant was discarded and $500 \mu \mathrm{L}$ of ethanol $80 \%$ was added, mixed and centrifuged for five minutes. The supernatant was then discarded and centrifuged for three minutes. Residual ethanol was removed by pipetting and pelleted DNA was eluted in $60 \mu \mathrm{L}$ of TrisEDTA. Milk samples were also pre-processed according to Reale, Campanella, Merigioli, and Pila (2008) method, with some modifications. $20 \mathrm{~mL}$ phosphate-buffered saline (PBS) was added to $20 \mathrm{~mL}$ fresh milk and centrifuged at $1500 \times g$ at $4{ }^{\circ} \mathrm{C}$ for $20 \mathrm{~min}$. Additional washing was performed by adding $10 \mathrm{~mL}$ PBS and the samples were centrifuged at $1500 \times g$ at $4{ }^{\circ} \mathrm{C}$ for $10 \mathrm{~min}$. The obtained pellet was resuspended in $60 \mu \mathrm{L}$ PBS and then subjected to DNA extraction using the protocol

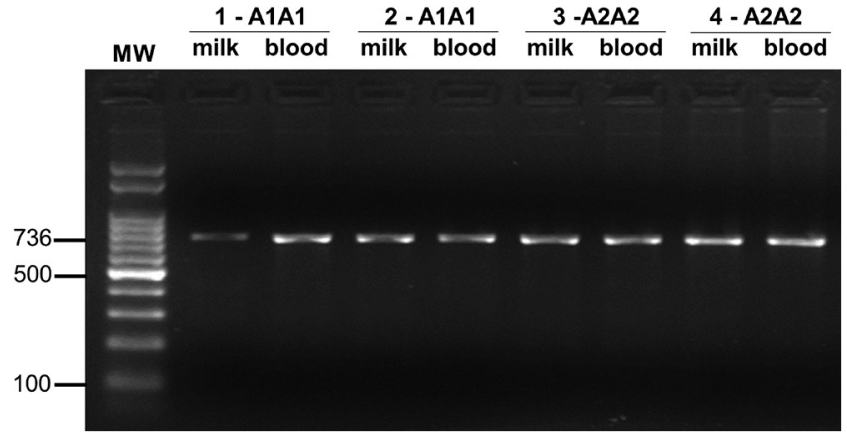

Fig. 1. Representative results obtained by electrophoresis of eight PCR products of CSN2 gene including A1 and A2 mutations (genotypes previously identified by sequencing), from milk and blood samples (four animals). The expected PCR fragment size was $736 \mathrm{bp}$. MW = Molecular-weight size marker $100 \mathrm{bp}$.

adopted for blood samples. The quantity and the purity of the extracted DNA were estimated by spectrophotometric readings at $260 \mathrm{~nm}$ and ratios of $260 / 280 \mathrm{~nm}$, respectively. The DNA concentrations of all tested samples were adjusted to $5 \mathrm{ng} / \mu \mathrm{L}$.

\subsection{DNA sequencing}

A set of primers (Supplementary Table 1) were constructed from sequences flanking a fragment of 736 nucleotides located in the bovine $\beta$-casein encoding gene (CSN2 gene; ID: 281099). The primers were designed using PrimerQuest software (http://www.idtdna.com/Primerquest/Home/Index). The specificity and the quality of the sequences were tested using the online tools NetPrimer (http:// www.premierbiosoft.com/netprimer/), OligoAnalyzer IDT (https:// www.idtdna.com/calc/analyzer) and BLAST (https://blast.ncbi.nlm.nih.gov/Blast.cgi?PROGRAM = blastn\&PAGET-

YPE $=$ BlastSearch\&LINKLOC $=$ blasthome).

The DNA extracted from milk and blood samples $(n=20)$ was submitted to PCR reactions. The assays were performed for a final volume of $50 \mu \mathrm{L}$ using $5 \mu \mathrm{L}$ of Platinum ${ }^{\mathrm{TM}}$ Taq DNA Polymerase High Fidelity ( $5 \mathrm{U} / \mu \mathrm{L}$; Invitrogen), $1.5 \mu \mathrm{L}$ of $\mathrm{MgSO}_{4}$ (Invitrogen), $0.2 \mu \mathrm{L}$ of Taq DNA Polymerase PCR Buffer $10 \times\left[\left(600 \mathrm{mM}\right.\right.$ Tris- $\mathrm{SO}_{4}(\mathrm{pH} 8.9)$, $180 \mathrm{mM}\left(\mathrm{NH}_{4}\right)_{2} \mathrm{SO}_{4}$; Invitrogen)], $1 \mu \mathrm{L}$ of $10 \mathrm{mM}$ dNTP mix (Sigma-Aldrich, St. Louis, USA), $2 \mu \mathrm{L}$ of each $10 \mu \mathrm{M}$ forward and reverse primer (Supplementary Table 1 ) and $2 \mu \mathrm{L}$ of DNA (10 ng). The PCR thermocycling conditions were as follows: initial denaturation at $95{ }^{\circ} \mathrm{C}$ for $5 \mathrm{~min}$, followed by 35 cycles at $95^{\circ} \mathrm{C}$ for $30 \mathrm{~s} \mathrm{(denaturation),}$ $55{ }^{\circ} \mathrm{C}$ for $45 \mathrm{~s}$ (annealing) and $72{ }^{\circ} \mathrm{C}$ for $1 \mathrm{~min}$ (extension), with a final extension at $72{ }^{\circ} \mathrm{C}$ for $10 \mathrm{~min}$. The amplification products were submitted to electrophoresis in $2.0 \%$ agarose gel, stained with ethidium bromide and visualised under ultraviolet light. The PCR products were purified using a PureLink ${ }^{\circledR}$ PCR purification kit (Invitrogen) according to the manufacturer's recommendations. PCR products from the same animal (blood and milk) were pooled and the DNA was sequenced using the same PCR primers. The sequencing reaction was performed using a BigDye Terminator v3.1 cycle sequencing kit (Applied Biosystems, Foster City, USA) and then analysed by an ABI Prism 3730XL DNA analyser (Applied Biosystems). The DNA sequences obtained were aligned using CLUSTAL/W software (Thompson, Higgins, \& Gibson, 1994) and compared to those already deposited in GenBank. The contig sequences were also evaluated by BLAST (http://blast.ncbi.nlm.nih. gov/Blast.cgi) and deposited in GenBank (access numbers: MK426695.1 and MK426696.1).

Following DNA sequence confirmation, two synthetic DNA gBlocks ${ }^{\circledR}$ Gene Fragments (Integrated DNA Technologies [IDT], Coralville, USA) were produced, each containing the specific sequence of either allele (A1 and A2) used as controls for the HRM and rhAmp assays. 


Allele CsN2 gene
Accession number

A2A2 MK426696.1 A2A2 MH378280.1 A2A2 JX273429.1 A2A2 KX618695.1 A2A2 KC993858.1 A2A2 XM 019962870.1 A2A2_JQ 408386.1 A2A2 EU310401.1 A2A2-JQ408388.1 A2A2 JN0 51276.1 A2A2_S67277.1 A1A1 X14711.1 A1A1_MK426696.1 A1A1 JX273430.1 A1A1_JQ408385.1 A1A1 JN051275.1 A1A1_XM_010806178.2 A1A1 XM 015471671.2

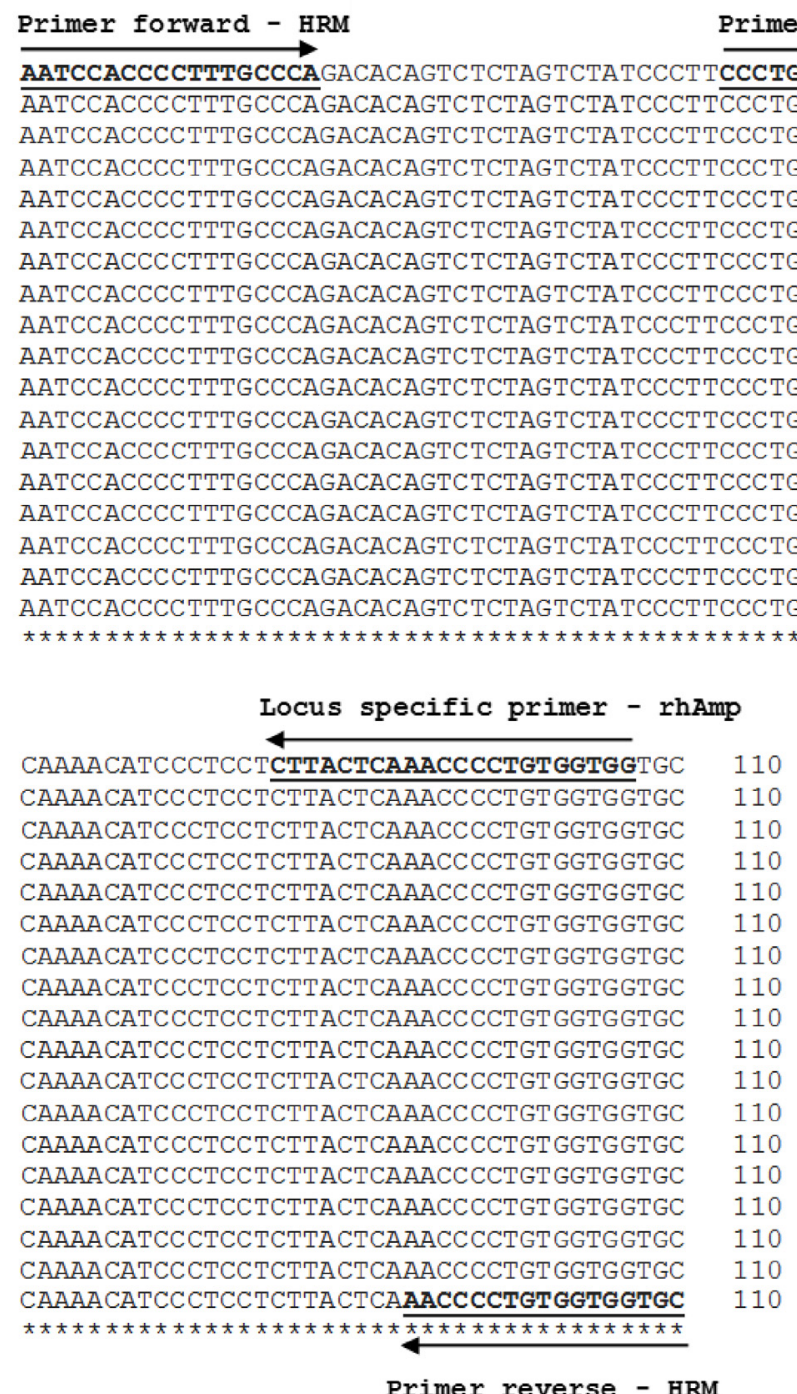

Primer reverse - HRM
САAАAСATС CTCCTCTTACTCAAACCCCTGTGGTGGTGC

СААААСАТСССТССТСTTACTCAAACCCCTGTGGTGGTGC 110 САAAAСATСССТСС TСTTACTCAAACCCCTGTGGTGGTGC 110

СAAAACATCССTCCTCTTACTCAAACCCCTGTGGTGGTGC 110

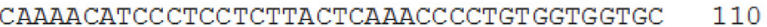
СААААСАТСССТССТСТTАСТСАААССССTGTGGTGGTGC 110 СААААСАТСССТССТСТTАСТСАAАCСCCTGTGGTGGTGC 110 СААААСАTСССТССТСТTACTCAAACCCCTGTGGTGGTGC 110 СААААСАTСССТССТСТTACTCAAACCCCTGT GGTGGTGC 110 110 110 110 110 110 110 110 10
Primer forward rhamp

AATCCACCCCTTTGCCCAGACACAGTCTCTAGTCTATCCCTTCCCTGGGCCCATCdCTAACAGCCTCCCA $\overline{\text { AATCCACCCCTTTGCCCA }}$ GACACAGTCTCTAGTCTATCCCTTCCCTGGGCCCATCQCFAACA AATCCACCCCTTTGCCCAGACACAGTCTCTAGTCTATCCCTTCCCTGGGCCCATCDCFAACAGCCTCCCA AATCCACCCCTTTGCCCAGACACAGTCTCTAGTCTATCCCTTCCCTGGGCCCATCOCFAACAGCCTCCCA AATCCACCCCTTTGCCCAGACACAGTCTCTAGTCTATCCCTTCCCTGGGCCCATCOCFAACAGCCTCCCA AATCCACCCCTTTGCCCAGACACAGTCTCTAGTCTATCCCTTCCCTGGGCCCATCOCFAACAGCCTCCCA ATCACCCCTTGCCCAGACACAGTCTCTAGTCTATCCCTTCCCTGGGCCCAT COCFAACAGCCTCCCA (1) TAGGCCATCOCAGCCTCCCA COAGACATCDAFAACAGCCTCCCA GGGCCATCDATAACAGCCTCCCA AATCCACCCCTTTGCCCAGACACAGTCTCTAGTCTATCCCT TCCCTGGGCCCAT COAFAACAGCCTCCCA AATCCACCCCTTTGCCCAGACACAGTCTCTAGTCTATCCCTTCCCTGGGCCCATC A AAACAGCCTCCCA 70 70 70 70 70 70 70 70 70 70 70 70 70 70 70 70 70 70

A2A2_MK426695.1
A2A2_MH378280.1
A2A2_JX273429.1
A2A2_KX618695.1
A2A2_KC993858.1
A2A2_XM_019962870.1
A2A2_JQ408386.1
A2A2_EU310401.1
A2A2_JQ408388.1
A2A2_JN051276.1
A2A2_S67277.1
A1A1_X14711.1
A1A1_MK426696.1
A1A1_JX273430.1
A1A1_JQ408385.1
A1A1_JN051275.1
A1A1_XM_010806178.2
A1A1_XM_015471671.2

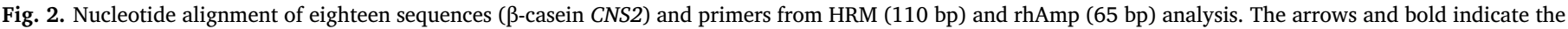

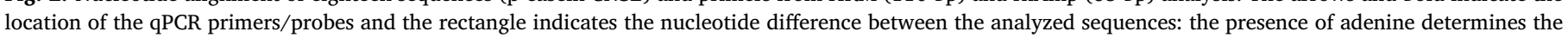

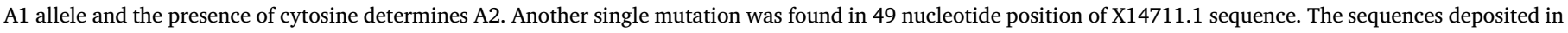
the study are A2A2_MK426695.1 and A1A1_MK426696.1.

\subsection{Real-time PCR assay followed by HRM analysis}

A set of primers flanking the SNP (single nucleotide polymorphism) associated with A1/A2 genotypes were constructed as described in Section 2.3, using the sequences MK426695.1 and MK426696.1.

A real-time PCR (qPCR), followed by HRM analysis, was performed in $10 \mu \mathrm{L}$ reaction volumes using a Rotor-Gene $\mathrm{Q}$ thermocycler (Qiagen, Venlo, Netherlands). Each reaction contained $6.4 \mu \mathrm{L}$ of sterile water, $2 \mu \mathrm{L}$ of $5 \times$ HOT FIREPol EvaGreen ${ }^{\circledR}$ HRM mix (Solis Biodyne, Tartu, Estonia), $0.3 \mu \mathrm{M}$ of each primer ( $\beta \mathrm{qPCRF}$ and $\beta \mathrm{qPCRR}$ ) and $1 \mu \mathrm{L}$ of DNA (5 ng). A negative template control was included in each PCR run. The qPCR was performed using the following conditions: initial denaturation at $95{ }^{\circ} \mathrm{C}$ for $12 \mathrm{~min}$, followed by 35 cycles of denaturation $\left(95^{\circ} \mathrm{C}\right.$ for $15 \mathrm{~s}$ ), annealing $\left(65^{\circ} \mathrm{C}\right.$ for $20 \mathrm{~s}$ ) and extension $\left(72{ }^{\circ} \mathrm{C}\right.$ for $\left.20 \mathrm{~s}\right)$. After amplification, HRM analysis for genotyping was performed during dissociation curves from 70 to $92{ }^{\circ} \mathrm{C}$ in $0.2{ }^{\circ} \mathrm{C}$ increments, rising at $0.1{ }^{\circ} \mathrm{C} / 2 \mathrm{~s}$. Standard samples (containing 500 DNA copies per reaction) of each genotype were included in all qPCR runs: A1A1 (A1 synthetic DNA or A1A1 animal sample previously sequenced), A2A2 (A2 synthetic DNA or A2A2 animal sample previously sequenced) and A1A2 ( $50 \%$ A1 synthetic DNA $+50 \%$ A2 synthetic DNA or $50 \%$ A1A1 animal sample previously sequenced $+50 \%$ A2A2 animal sample previously sequenced).

The reactions were carried out in $100 \mu \mathrm{L}$ microtubes (PCR ${ }^{\circledast}$ strip tubes and caps; Product no. PCR-0104-C; Axygen ${ }^{\circledR}$, New York, USA) using a Rotor-Gene Q (Qiagen) equipped with a 72-well rotor. RotorGene Q software was used to analyse and determine the genotypes, using a confidence value of $\geq 90 \%$.

\section{5. $r h A m p^{\circledast}$ SNP genotyping}

The rhAmp ${ }^{\circledast}$ Genotyping Design Tool (IDT; https://eu.idtdna.com/ site/order/designtool/index/GENOTYPING_PREDESIGN) was used to design the primers, resulting in the assay ID: CD.GT.QWDC2715.6 (Supplementary Table 1). The rhAmp genotyping assay was performed by following the manufacturer's instructions. Briefly, $2 \mu \mathrm{L}(10 \mathrm{ng})$ of DNA sample was mixed with $5.3 \mu \mathrm{L}$ of rhAmp Genotyping Mix [1 mL of rhAmp Genotyping Master Mix $2 \times$ (Cat. no. 1076017; IDT) and $50 \mu \mathrm{L}$ 

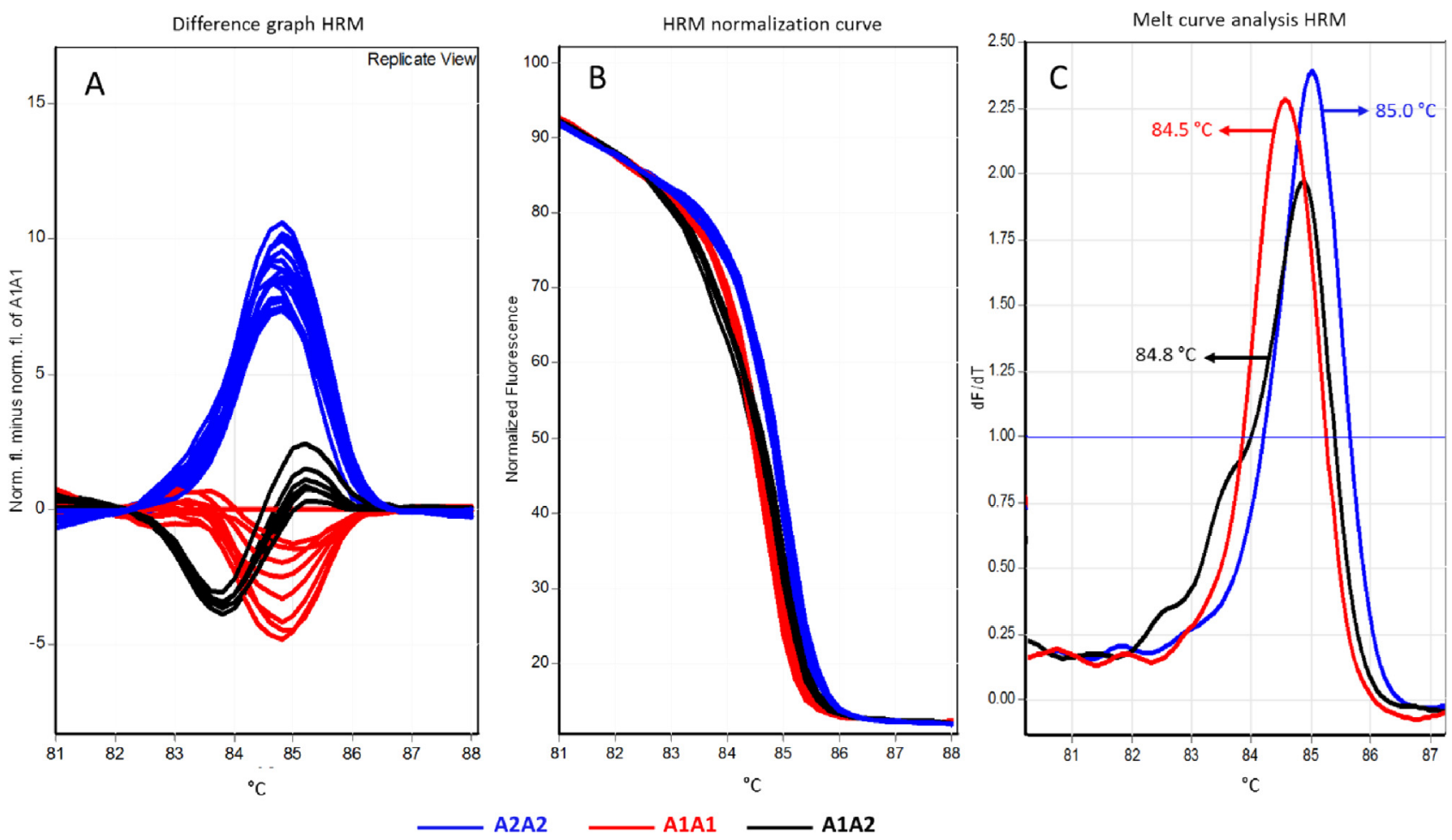

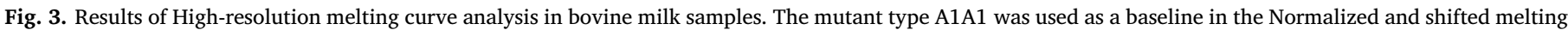

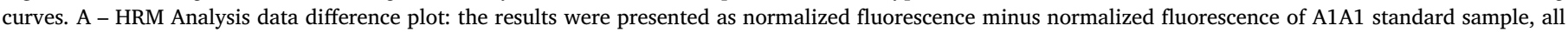

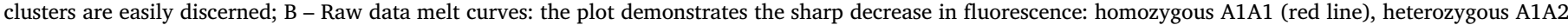

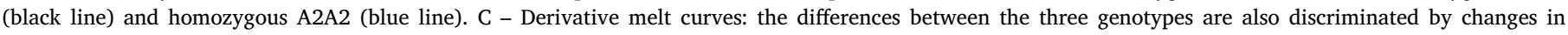

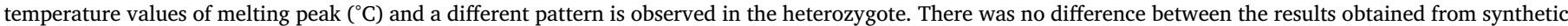

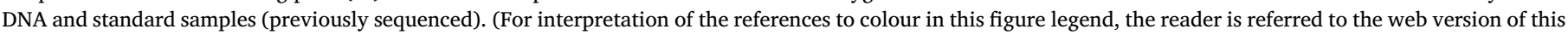
article.)

of rhAmp Reporter Mix (Cat. no. 1076028; IDT)] and $0.5 \mu \mathrm{L}$ of custom rhAmp SNP assays (IDT), attaining a final volume of $10 \mu \mathrm{L}$. The same standard samples and negative template controls used in the HRM analysis were also included in this assay. The thermal cycling conditions were $95{ }^{\circ} \mathrm{C}$ for $10 \mathrm{~min}$ (enzyme activation), followed by 40 cycles of denaturation $\left(95{ }^{\circ} \mathrm{C}\right.$ for $\left.10 \mathrm{~s}\right)$, annealing $\left(60{ }^{\circ} \mathrm{C}\right.$ for $\left.30 \mathrm{~s}\right)$ and extension $\left(68^{\circ} \mathrm{C}\right.$ for $\left.20 \mathrm{~s}\right)$, plus a final heat inactivation $\left(99.9^{\circ} \mathrm{C}\right.$ for $\left.15 \mathrm{~min}\right)$. Rotor-Gene $\mathrm{Q}$ operating software was used to determine allelic discrimination and to analyse and ascertain the genotypes, using a confidence value of $\geq 90 \%$.

\subsection{A1 allele identification in A2 samples}

The limits of detection of both developed qPCR methods were determined by testing tenfold serial dilutions of synthetic DNA from A1A1 or A2A2 genotypes (from $4 \times 10^{9}$ DNA copies to $4 \times 10^{-1}$ DNA copies). Briefly, decreasing concentrations of A1 in A2 synthetic DNA were tested as follows: $50 \%$ (500 copies), $40 \%$ (400 copies), 30\% (300 copies), $20 \%$ (200 copies), 10\% (100 copies), 5\% (50 copies), $2 \%$ (10 copies) and $1 \%$ ( 5 copies). These tests were also performed using DNA samples from previously genotyped animals, replacing A1 and A2 synthetic DNAs by A1A1 and A2A2 DNA samples, respectively.

\section{Results}

\subsection{DNA sequencing}

The PCR products from the primer set $\beta$ PCRF and $\beta$ PCRR were specific, as observed in Fig. 1. All A1A1- and A2A2-sequenced DNA samples showed $100 \%$ of homology compared to respective A1A1 and A2A2 sequences previously deposited in GenBank, with the exception of the A1A1_X17411.1 sequence, which presented another mutation at nucleotide position 49 (Fig. 2).

\subsection{HRM genotyping}

All tested samples were successfully genotyped for the three possible genotypes (A1A1, A1A2 and A2A2) via HRM analysis. The three genotypes were easily identified, especially due to their different melting temperature peaks (Fig. 3c) and their positive or negative peaks of normalised fluorescence minus fluorescence of A1A1 control (Fig. 3a). For each genotype, the same patterns were observed between different milk and blood samples from different animals and controls (gBlocks and sequenced samples). The genotype frequencies of evaluated animals for A1A1, A1A2 and A2A2 were $36 \%, 31 \%$ and $33 \%$, respectively. The five commercial samples from five different milking batches presented the A2A2 genotype.

\section{3. rhAmp genotyping}

The rhAmp assays successfully genotyped all of the milk samples evaluated. Fig. 4a and $\mathrm{b}$ present the amplification curves from two channels: green (FAM) and yellow (YY). The green channel (FAM) detected the A2 allele (wild allele), while the yellow channel (VIC) detected the A1 allele (mutant allele). Both signals detected the heterozygous variant (A1A2). As observed in the HRM analyses, the standard samples and the milk samples presented the same patterns as each other (Fig. 4).

\subsection{A1 allele identification in A2 samples}

Regarding the sensitivities of the methods developed for the 

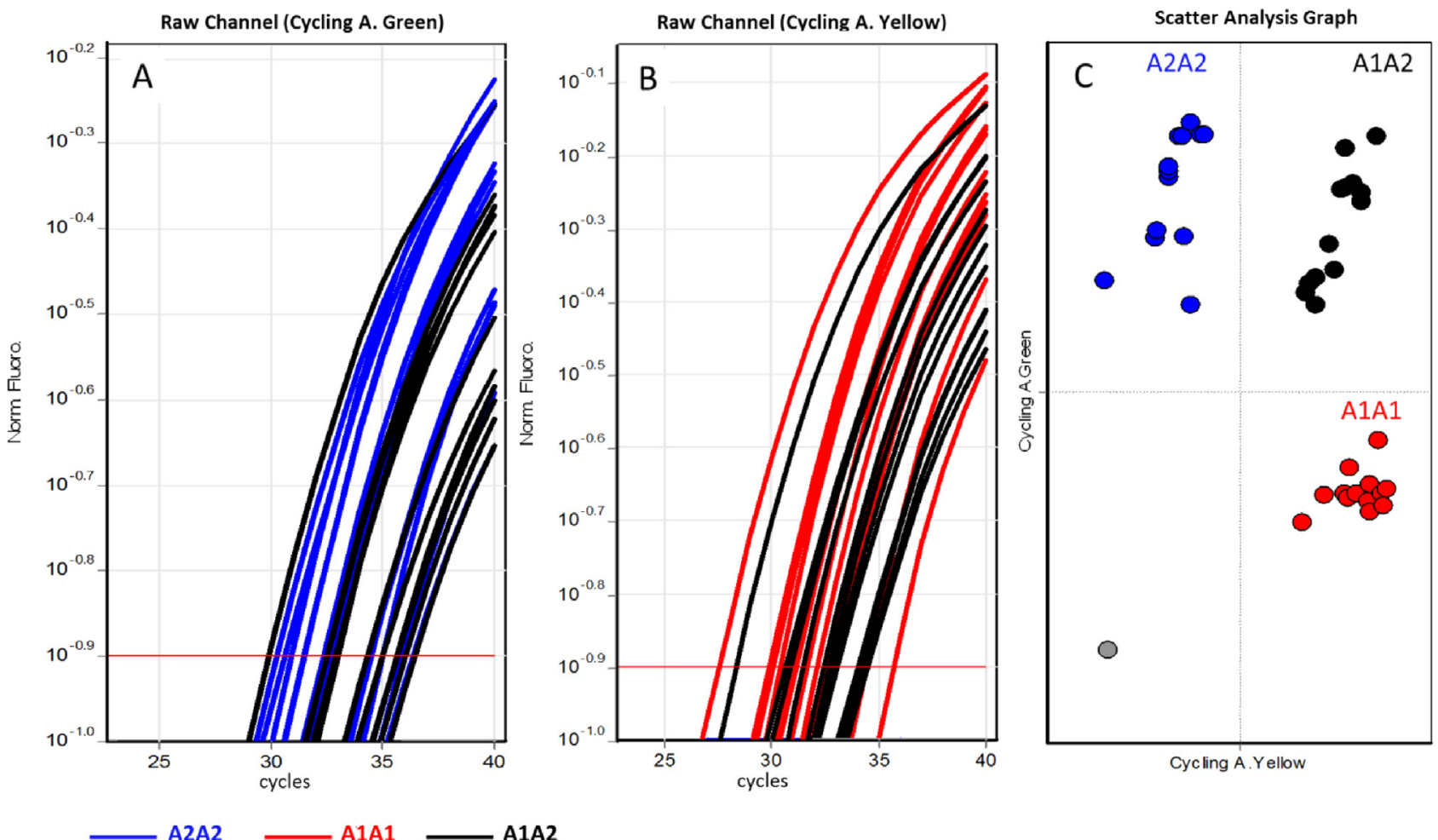

Fig. 4. Amplification curve (A and B) and allelic discrimination plots (C) for SNPs located in CSN2 gene obtained by rhAmp genotyping assays on 35 milk samples. The biallelic discrimination was achieved through the competitive binding of two allele-specific forward primers, one labeled with FAM dye and the other with Yakima Yellow (YY) dye. Nonspecific amplifications were not observed. In C: Red (A1) and blue (A2) dots represent the homozygous genotypes, the black circles represent heterozygous genotypes and the grey circle on the bottom left of the plot is no-template control. Quantitative cycles are represented on a logarithmic scale (A and B). (For interpretation of the references to colour in this figure legend, the reader is referred to the web version of this article.)

Table 1

Results of analytical sensitivity tests for A1 identification in A2 samples by HRM and rhAmp assays using synthetic DNA and sequenced samples. Red letters highlight the A1 concentrations below the limits of detection.

\begin{tabular}{|c|c|c|c|c|}
\hline \multirow[b]{2}{*}{ Sample type } & \multicolumn{3}{|c|}{ HRM analysis } & \multirow{2}{*}{$\mathrm{rhAmp}^{\mathrm{TN}}$} \\
\hline & $\% \mathrm{~A} 1$ in $\mathrm{A} 2$ & Genotype & Confidence $\%{ }^{*}$ & \\
\hline \multirow{10}{*}{$\begin{array}{l}\text { Sequenced } \\
\text { sample }\end{array}$} & 100 & A1A1 & 99.4 & $\mathrm{~A} 1 \mathrm{~A} 1$ \\
\hline & 50 & $\mathrm{~A} 1 \mathrm{~A} 2$ & 99.7 & $\mathrm{~A} 1 \mathrm{~A} 2$ \\
\hline & 40 & $\mathrm{~A} 1 \mathrm{~A} 2$ & 99.2 & $\mathrm{~A} 1 \mathrm{~A} 2$ \\
\hline & 30 & $\mathrm{~A} 1 \mathrm{~A} 2$ & 99.2 & $\mathrm{~A} 1 \mathrm{~A} 2$ \\
\hline & 20 & $\mathrm{~A} 1 \mathrm{~A} 2$ & 96.4 & $\mathrm{~A} 1 \mathrm{~A} 2$ \\
\hline & 10 & $\mathrm{~A} 1 \mathrm{~A} 2$ & 94.4 & $\mathrm{~A} 1 \mathrm{~A} 2$ \\
\hline & 5 & Variation & - & $\mathrm{A} 1 \mathrm{~A} 2$ \\
\hline & 2 & $\mathrm{~A} 2 \mathrm{~A} 2$ & 99.6 & $\mathrm{~A} 1 \mathrm{~A} 2$ \\
\hline & 1 & $\mathrm{~A} 2 \mathrm{~A} 2$ & 98.9 & $\mathrm{~A} 2 \mathrm{~A} 2$ \\
\hline & 0 (A2A2) & $\mathrm{A} 2 \mathrm{~A} 2$ & 99.4 & $\mathrm{~A} 2 \mathrm{~A} 2$ \\
\hline \multirow{10}{*}{ Synthetic DNA } & 100 & $\mathrm{~A} 1 \mathrm{~A} 1$ & 98.7 & A1A1 \\
\hline & 50 & $\mathrm{~A} 1 \mathrm{~A} 2$ & 92.9 & $\mathrm{~A} 1 \mathrm{~A} 2$ \\
\hline & 40 & $\mathrm{~A} 1 \mathrm{~A} 2$ & 95.2 & $\mathrm{~A} 1 \mathrm{~A} 2$ \\
\hline & 30 & $\mathrm{~A} 1 \mathrm{~A} 2$ & 94.8 & $\mathrm{~A} 1 \mathrm{~A} 2$ \\
\hline & 20 & $\mathrm{~A} 1 \mathrm{~A} 2$ & 98.1 & $\mathrm{~A} 1 \mathrm{~A} 2$ \\
\hline & 10 & $\mathrm{~A} 1 \mathrm{~A} 2$ & 97.7 & $\mathrm{~A} 1 \mathrm{~A} 2$ \\
\hline & 5 & $\mathrm{~A} 1 \mathrm{~A} 2$ & 98.9 & $\mathrm{~A} 1 \mathrm{~A} 2$ \\
\hline & 2 & $\mathrm{~A} 2 \mathrm{~A} 2$ & 95.6 & $\mathrm{~A} 1 \mathrm{~A} 2$ \\
\hline & 1 & $\mathrm{~A} 2 \mathrm{~A} 2$ & 96.9 & $\mathrm{~A} 2 \mathrm{~A} 2$ \\
\hline & $0(\mathrm{~A} 2 \mathrm{~A} 2)$ & $\mathrm{A} 2 \mathrm{~A} 2$ & 98.9 & $\mathrm{~A} 2 \mathrm{~A} 2$ \\
\hline
\end{tabular}

$* \%$ confidence refers to the means of the duplicates of each sample and for each method.

identification of A1 allele presence in the A2 samples, the HRM analysis showed a limit of detection of $10 \%$ (100 copies), whereas for rhAmp the limit was $2 \%$ ( 10 copies). Table 1 presents the results of the genotyping via HRM and rhAmp techniques. Improved efficiencies of A1 detection in the A2 samples were found for both methods. When synthetic DNA was used, the observed limits were $5 \%$ (50 copies) and 2\% (10 copies) for HRM and rhAmp, respectively (Table 1 and Fig. 5).

\section{Discussion}

A2 $\beta$-casein milk is becoming increasingly popular among consumers and producers. Farmers in many regions of the world are being encouraged to produce A2 milk to meet the demand for this product, which is considered a healthier alternative to conventional dairy (Bell, Grochoski, \& Clarke, 2006). Brazil has recently started to produce commercial A2 milk. Currently, A1-free bovine milk is being marketed in several countries, including Australia, the United Kingdom, the United States, New Zealand and the Netherlands (Brooke-Taylor et al., 2017).

This study is the first attempt to develop HRM and rhAmp assays for genotyping CSN2 alleles in milk samples. Most researchers were focused on identifying the frequencies of these genotypes in the animals (Chessa, Bulgari, Rossoni, Ceriotti, \& Caroli, 2013; Dai et al., 2016; Ganguly et al., 2013; Rangel et al., 2017; Royo et al., 2014; Sharma et al., 2013). Although we have also determined the genotypic frequencies, these results were not the main focus of this study. The priority was to develop a rapid and high-sensitive method for A1 allele identification in A2 milk samples. The final concentrations of the DNA extracted from samples of milk (each animal) ranged from 10 to $100 \mathrm{ng} / \mu \mathrm{L}$ (data not shown), which allowed the dilution to $5 \mathrm{ng} / \mu \mathrm{L}$, which was then used in both genotyping methods. This variation of DNA quantity may be associated with the number of somatic cells present in the milk. Although the somatic cell count in milk is used as an important indicator of udder health, it may also be influenced by several factors, such as animal species, milk production level, lactation stage, and individual and environmental factors, as well as management practices (Li, Richoux, Boutinaud, Martin, \& Gagnaire, 2014).

The HRM and rhAmp methods developed facilitated the identification of the two most common variants of bovine $\beta$-casein, with considerable accuracy. The sequenced PCR products demonstrated that the 


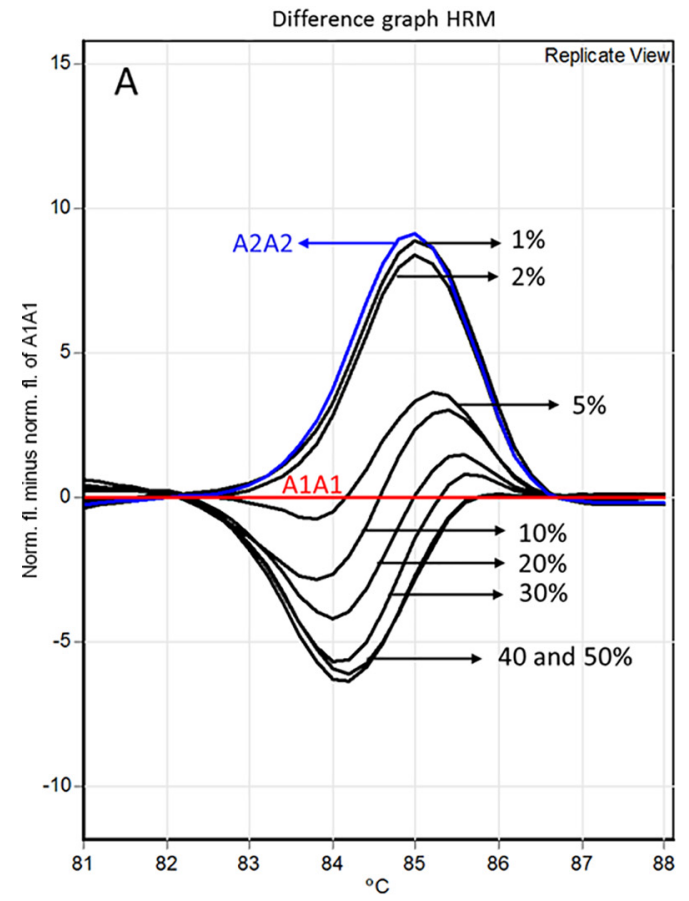

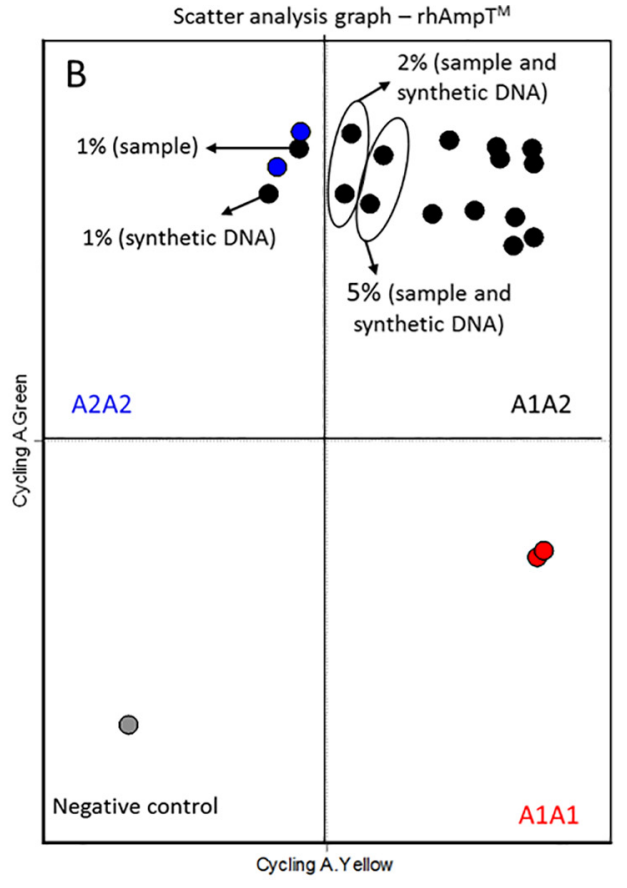

Fig. 5. Analytical sensitivity test for $A 1$ identification in A2 samples for HRM analysis (A) and rhAmp genotyping (B). Synthetic DNA and sequenced DNA samples containing initially the proportion $50 \%$ of each allele (500 copies of each allele), the percentages of A1 were progressively decreased: 50\% (500 copies), 40\% (400 copies), 30\% (300 copies), 20\% (200 copies), 10\% (100 copies), 5\% (50 copies), 2\% (10 copies) and $1 \%$ (5 copies). The values of HRM analysis are showed as replicates means between gBlocks and sequencing samples, while for rhAmp test are separated. region flanked by primers (HRM) and probes (rhAmp) was highly conserved and contained only the mutation C/A (A2 to A1). The identity between the 10 sequenced samples and genotyped sequences previously deposited in GenBank was $100 \%$, enabling their use as positive controls in subsequent analyses. The synthetic fragments' gBlocks were also used as positive controls and presented the same patterns as the sequenced samples.

In the HRM analysis, changes in the shape of the normalised curves were observed between the different genotypes. The rhAmp genotyping also enabled the three genotypes to be discriminated. Thus, both methods proved to be highly reliable for the determination of the homozygous $\mathrm{A} 1 \mathrm{~A} 1$ and $\mathrm{A} 2 \mathrm{~A} 2$ and the heterozygous A1A2 genotypes in samples obtained from both blood and milk. In this study, we used animals that had been genotyped from a milk producer of A2A2 cows. For both techniques, there was $100 \%$ agreement with the previous genotyping results of these animals. Therefore, we suggest that both strategies might be used, instead of the DNA sequencing technique.

Given that demand for the consumption of A2 (A2A2) milk is increasing across the world (Gaudry et al., 2019), accurate methods by which to identify the A1 allele in milk commercialized as A2 are also highly valuable. Consequently, identification of animal genotypes may be not completely sufficient. Rather, a method that detects a minimal presence of the A1 allele in milk samples commercialised as A2 could prove to be an excellent tool. The HRM and rhAmp assays used here detected the presence of allele A1 in A2 samples at rates of $10 \%$ (100 copies) and 2\% (10 copies), respectively. The rhAmp was ten times more sensitive than HRM analysis for this purpose. However, when synthetic DNA was used, the limits of detection were $5 \%$ and $2 \%$ for HRM and rhAmp, respectively. Thus, we may conclude that both methods are highly sensitive for genotyping animals from milk samples. Nevertheless, we recommend the rhAmp method to detect the contamination of A1 in A2 samples, due to its increased sensitivity.

Literature studies standardising the HRM method for the genotyping of variants A1 and A2 remain scarce. Sharma et al. (2013) genotyped 314 cows from various places in North India by HRM analysis in order to discriminate $\beta$-casein A1 from A2, ultimately deeming this method a straightforward strategy to detect and characterise these genotypes. Royo et al. (2014) have also used HRM analysis to identify A1 and A2 genotypes simultaneously, with the method proving to be a good alternative for routine typing of a low or medium number of polymorphisms, as true of the most frequent $\beta$-casein variants. The present study has represented the first attempt to standardise the rhAmp method for genotyping $\beta$-casein A1 and A2 allelic variants. A similar investigation by Manga and Dvořák (2010) to distinguish between A1 and A2 alleles using hydrolysis probes system (TaqMan), found $100 \%$ of genotyping accuracy and a 100-fold greater degree of sensitivity than ACRS-PCR (amplification created restriction site method followed by PCR assay) method.

\section{Conclusions}

In conclusion, this study has demonstrated that HRM and rhAmp methods reliably discriminate and detect A1A1, A2A2 and A1A2 genotypes of the CSN2 gene in milk samples. Although both techniques presented $100 \%$ accuracy for genotyping animals, the rhAmp demonstrated ten times greater sensitivity than the HRM method in terms of its sensitivity towards the presence of small quantities of A1 in an A2 sample. Thus, it is confidently suggested here that rhAmp could be used to detect small quantities of the A1 allele in A2 samples and hence to identify A1 in milk commercialised as A2.

\section{CRediT authorship contribution statement}

Rodrigo Giglioti: Conceptualization, Data curation, Formal analysis, Investigation, Methodology, Project administration, Software, Supervision, Validation, Visualization, Writing - original draft, Writing review \& editing. Gunta Gutmanis: Conceptualization, Supervision, Validation, Visualization, Writing - original draft, Writing - review \& editing. Luciana Morita Katiki: Conceptualization, Supervision, Validation, Visualization, Writing - original draft, Writing - review \& editing. Cintia Hiromi Okino: Conceptualization, Data curation, Formal analysis, Investigation, Methodology, Project administration, Software, Supervision, Validation, Visualization, Writing - original draft, Writing - review \& editing. Márcia Cristina de Sena Oliveira: Conceptualization, Supervision, Validation, Visualization, Writing original draft, Writing - review \& editing. Aníbal Eugênio VercesiFilho: Funding acquisition, Investigation, Project administration, Resources, Supervision, Validation, Visualization, Writing - original 
draft, Writing - review \& editing.

\section{Declaration of Competing Interest}

The authors declare that they have no known competing financial interests or personal relationships that could have appeared to influence the work reported in this paper.

\section{Acknowledgements}

This work was supported by the National Council for Scientific and Technological Development (CNPq) (grant number Projeto Universal \#426876/2016-4) and the Instituto de Zootecnia, Nova Odessa, Brazil.

\section{Appendix A. Supplementary data}

Supplementary data to this article can be found online at https:// doi.org/10.1016/j.foodchem.2020.126167.

\section{References}

Bell, S. J., Grochoski, G. T., \& Clarke, A. J. (2006). Health implications of milk containing $\beta$-casein with the A2 genetic variant. Critical Reviews in Food Science and Nutrition, 46, 93-100.

Bonfatti, V., Di Martino, G., Cecchinato, A., Vicario, D., \& Carnier, P. (2010). Effects of $\beta$ $\kappa$-casein (CSN2-CSN3) haplotypes and $\beta$-lactoglobulin (BLG) genotypes on milk production traits and detailed protein composition of individual milk of Simmental cows. Journal of Dairy Science, 93, 3797-3808.

Brooke-Taylor, S., Dwyer, K., Woodford, K., \& Kost, N. (2017). Systematic review of the gastrointestinal effects of A1 compared with A2 $\beta$-Casein. Advances in Nutrition, 8(5), 739-748.

Chessa, S., Bulgari, O., Rossoni, A., Ceriotti, G., \& Caroli, A. M. (2013). Bovine $\beta$-casein: detection of two single nucleotide polymorphisms by bidirectional allele specific polymerase chain reaction (BAS-PCR) and monitoring of their variation. Open Journal of Animal Sciences, 3(1), 36-41.

Chia, J. S. L., McRae, J. L., Kukuljan, S., Woodford, K., Elliott, R. B., Swinbum, B., \& Dwyer, K. M. (2017). A1 beta-casein milk protein and other environmental pre-disposing factors for type 1 diabetes. Nutrition \& Diabetes, 7(274), 1-7.

Dai, R., Fang, Y., Zhao, W., Liu, S., Ding, J., Xu, K., ... Meng, H. (2016). Identification of alleles and genotypes of beta-casein with DNA sequencing analysis in Chinese Holstein cow. Journal of Dairy Research, 83, 312-316.

De Noni, I. (2008). Release of beta-casomorphins 5 and 7 during simulated gastro-intestinal digestion of bovine beta-casein variants and milk-based infant formulas. Food Chemistry, 110, 897-903.

De Noni, I., \& Cattaneo, S. (2010). Occurrence of beta-casomorphins 5 and 7 in commerical dairy products and in their digests following in vitro simulated gastrointestinal digestion. Food Chemistry, 199, 560-566.

Dobosy, J. R., Rose, S. D., Beltz, K. R., Rupp, S. M., Powers, K. M., Behlke, M. A., \& Walder, J. A. (2011). RNase H-dependent PCR (rhPCR): Improved specificity and single nucleotide polymorphism detection using blocked cleavable primers. BMC Biotechnology, 11, 80.

Farrell, H. M., Jr., Jimenez-Flores, R., Bleck, G. T., Brown, E. M., Butler, J. E., Creamer, L. K., et al. (2004). Nomenclature of the proteins of cows' milk-sixth revision. Journal Dairy Science, 87, 1641-1674.

Ganguly, I., Kumar, S., Gaur, G. K., Singh, U., Kumar, A., Kumar, S., et al. (2013). Status of $\beta$-casein (CSN2) polymorphism in Frieswal (HF X Sahiwal Crossbred) cattle. International Journal of Biotechnology and Bioengineering Research, 4(3), 249-256.

Gaudry, K. D., Lohner, S., Schmucker, C., Kapp, P., Motschall, E., Hörrlein, S., et al. (2019). Milk A1 $\beta$-casein and health-related outcomes in humans: A systematic review. Nutrition Reviews, 77(5), 278-306.

Grosclaude, F. (1988). Le polymorphism e génétique des principales lactoprotéines bovines: Relations avec la quantité, la composition etles aptitudes fromagères du lait. INRA Productiones Animales, 1, 5-17.

Gustavsson, F., Buitenhuis, A. J., Johansson, M., Bertelsen, H. P., Glantz, M., Poulsen, N. A., et al. (2014). Effects of breed and casein genetic variants on protein profile in milk from Swedish Red, Danish Holstein, and Danish Jersey cows. Journal of Dairy Science, 97(6), 3866-3877.

He, M., Sun, J., Jiang, Z. Q., \& Yang, Y. X. (2017). Effects of cow's milk beta-casein variants on symptoms of milk intolerance in Chinese adults: A multicentre, randomised controlled study. Nutrition Journal, 16(72), 1-12.

Jarmołowska, B., Bukało, M., Fiedorowicz, E., Cieślińska, A., Kordulewska, N. K., Moszyńska, M., et al. (2019). Role of milk-derived opioid peptides and proline dipeptidyl peptidase-4 in autism. Spectrum Disorders > Nutrients, 11(1), 1-13 87.

Jianqin, S., Leiming, X., Lu, X., Yelland, G. W., Ni, J., \& Clarke, A. J. (2016). Effects of milk containing only A2 beta casein versus milk containing both A1 and A2 beta casein proteins on gastrointestinal physiology, symptoms of discomfort, and cognitive behavior of people with self-reported intolerance to traditional cows' milk. Nutrition Journal, 15(35), 1-16.

Jinsmaa, Y., \& Yoshikawa, M. (1999). Enzymatic release of neocasomorphin and $\beta$-casomorphin from bovine b-casein. Peptides, 20, 957-962.

Kamiński, S., Cieślińska, A., \& Kostyra, E. (2007). Polymorphism of bovine beta-casein and its potential effect on human health. Journal of Applied Genetics, 48(3), 189-198.

Kamiński, S., Ruść, A., \& Cieślińska, A. (2006). A note on frequency of A1 and A2 variants of bovine beta-casein locus in Polish Holstein bulls. Journal of Animal and Feed Sciences, 15, 195-198.

Keating, A. F., Smith, T. J., Ross, R. P., \& Cairns, M. T. (2008). A note on the evaluation of a beta-casein variant in bovine breeds by allele-specific PCR and relevance to betacasomorphin. Irish Journal of Agricultural and Food Research, 47, 99-104.

Li, N., Richoux, R., Boutinaud, M., Martin, P., \& Gagnaire, V. (2014). Role of somatic cells on dairy processes and products: A review. Dairy Science \& Technology, 94(6), $517-538$.

Lien, S., Kantanen, J., Olsaker, I., Holm, L. E., Eythorsdottir, E., Sandberg, K., et al. (1999). Comparison of milk protein allele frequencies in Nordic cattle breeds. Animal Genetics, 30(2), 85-91.

Manga, I., \& Dvořák, J. (2010). TaqMan allelic discrimination assay for A1 and A2alleles of the bovine CSN2 gene. Czech Journal Animal Science, 55(8), 307-312.

Nguyen, D. D., Johnson, S. K., Busetti, F., \& Solah, V. A. (2015). Formation and degradation of beta-casomorphins in dairy processing. Critical Reviews in Food Science and Nutrition, 55(14), 1955-1967.

Rangel, A. H. N., Zaros, L. G., Lima, T. C., Borba, L. H. F., Novaes, L. P., Mota, L. F. M., \& Silva, M. S. (2017). Polymorphism in the Beta Casein Gene and analysis of milk characteristics in Gir and Guzerá dairy cattle. Genetics and Molecular Research, 16(2), 1-9.

Reale, S., Campanella, A., Merigioli, A., \& Pila, F. (2008). A novel method for species identification in milk and milk-based products. Journal of Dairy Research, 75, $107-112$.

Royo, L. J., del Cerro, A., Vicente, F., Carballal, A., \& Roza-Delgado, B. (2014). An accurate high-resolution melting method to genotype bovine $\beta$-casein. European Food Research and Technology, 238, 295-298.

Severance, E. G., Dickerson, F. B., Halling, M., Krivogorsky, B., Haile, L., Yang, S., et al (2010). Subunit and whole molecule specificity of the anti-bovine casein immune response in recent onset psychosis and schizophrenia. Schizophrenia Research, 118 240-247.

Sharma, V., Sharma, N., Jawed, B., Chandra, S., Nautiyal, S. C., \& Singh, R. K. (2013). High resolution melt curve analysis for the detection of A1, A2 $\beta$-casein variants in Indians cows. Journal of Microbiology and Biotechnology Research, 3(1), 144-148.

Thompson, J. D., Higgins, D. G., \& Gibson, T. J. (1994). CLUSTAL W: Improving the sensitivity of progressive multiple sequence alignment through sequence weighting, position-specific gap penalties and weight matrix choice. Nucleic Acids Research, 22(22), 4673-4680.

Visioli, F., \& Strata, A. (2014). Milk, dairy products, and their functional effects in humans: A narrative review of recent evidence. Advances in Nutrition, 5(2), 131-143.

Visker, M. H., Dibbits, B. W., Kinders, S. M., van Valenberg, H. J., van Arendonk, J. A., \& Bovenhuis, H. (2010). Association of bovine b-casein protein variant I with milk production and milk protein composition. Animal Genetics, 42, 212-218.

Visser, S., Slangen, C. J., \& Rollema, H. S. (1991). Phenotyping of bovine milk proteins by reversed-phase high performance liquid chromatography. Journal of Chromatography, 548, 361-370.

Whiteley, P., Haracopos, D., Knivsberg, A. M., Reichelt, K. L., Parlar, S., Jacobsen, J., et al. (2010). The ScanBrit randomised, controlled, single-blind study of a gluten-and casein-free dietary intervention for children with autism spectrum disorders. Nutritional Neuroscience, 13(2), 87-100.

Wittwer, C. T., Reed, G. H., Gundry, C. N., Vandersteen, J. G., \& Pryor, R. (2003). Highresolution genotyping by amplicon melting analysis using LCGreen. Clinical Chemistry, 49, 853-860. 